\title{
Transformative Pedagogies for Sustainable Development
}

\section{Salonen, Arto O.}

Springer

2019

Salonen , A O \& Siirilä , J 2019 , Transformative Pedagogies for Sustainable Development . in W Leal Filho (ed.), Encyclopedia of Sustainability in Higher Education . Springer, Cham , pp. 1-7 . https://doi.org/10.1007/978-3-319-63951-2_369-1

http://hdl.handle.net/10138/327588

https://doi.org/10.1007/978-3-319-63951-2_369-1

unspecified

acceptedVersion

Downloaded from Helda, University of Helsinki institutional repository.

This is an electronic reprint of the original article.

This reprint may differ from the original in pagination and typographic detail.

Please cite the original version. 


\section{Transformative Pedagogies for Sustainable Development}

\section{New ideal of the good life is needed}

In a new geologic epoch - the Anthropocene epoch - humankind is the biggest individual determiner of the future of planet Earth, which means that the future is in the hands humans more than ever before (Crutzen 2002). In other words, the effect of humans on the atmosphere, oceans and nature is great enough to leave permanent impacts (Rocktström et al. 2009). The species Homo sapiens is destroying the natural systems that maintain all life (Ripple et al. 2018).

Our children will live in a world where wild areas are reduced, where there are fewer animal and plant species, where fewer areas are available for food production, where natural resources are declining and the climate is more volatile (Marsh 1965; Ward \& Dubos 1972; Budowski 1984; Ehrlich et al. 2012; Wiedmann et al. 2015; United Nations, 2015; Ripple et al. 2018). Thus, holistic societal change is needed to create safe and fair operating space for humanity. These changes are among the biggest learning challenges facing humankind (Åhlberg et al., 2014).

In the history of mankind, a fatalistic way of thinking has been replaced with a new understanding. People have started to understand that they can be creators of their common future. Therefore, two kinds of future strategies have been developed. Political strategy emphasizes innovation and technological progress that is regulated by decision makers. Pedagogical strategy is based on the relevance of identities, values and ethical frameworks. This strategy is emphasized, for example, by behavioural economics, behavioural sciences and education sciences (Hämäläinen, 2015, 1023).

The World Commission on Environment and Development presented sustainable development as a model of holistic social change (WCED 1987, 46). Fundamentally sustainable development is about the transformation of basic aspects of the present ideal of material well-being to protect the natural systems that maintain human and non-human life (Baker, 2006). In its deepest sense, this means that the main goal of learning is seeing things differently instead of doing things better or even doing better things (Bateson, 1972; Sterling, 2010).

Later, quality of social change is described by the Agenda 2030 action plan. It came into effect in the beginning of 2016. The 17 universally accepted goals and 169 targets at its core apply equally to all countries (United Nations 2016). The main purpose of the Agenda 2030 is noble: "We resolve, between now and 2030, to end poverty and hunger everywhere; to combat inequalities within and among countries; to build peaceful, just and inclusive societies; to protect human rights and promote gender equality and the empowerment of women and girls; and to ensure the lasting protection of the planet and its natural resources." (United Nations, 2015).

Transformative pedagogies for sustainable development ask how we human beings could, as decision makers and citizens, change the direction of development that seems to be 
inevitable. How does learning transform humans and human-environment relationships? How could students integrate personal transformation pathways in attempts to shape material and social changes. Which social factors could drive humanity to move away from unsustainability? How can societal transformations be accelerated towards sustainable development goals?

\section{Implementation of Agenda 2030: From behavioural changes to social change}

Even if humankind face great challenges, we are able to overcome them. Societies are becoming more affluent. People are more prosperous than ever, and the amount of available information is enormous. Freeing citizens from extreme poverty is no longer the main object of national governments. Therefore, broader examination of well-being enables recognizing the heart of progress. The conception that education as a social process and function is in vain until we define the ideal of society we have in mind (Dewey, 1916).

There is a common vision concerning the notions of what is good life and progress in society. People from different background agree that peace is better than war and equal rights are better than discrimination. We also think that happiness is better than misery, and opportunities to enjoy family, friends, culture, and nature are crucial in life (Pinker, 2018). In the other words, progress and a better future is clearly defined as a shared vision in Agenda 2030 (United Nations 2015). It pursues a peaceful, sustainable society, comprised of more personally fulfilled people, making full use of their potential (Fadel, Bialik \& Trilling 2015, 7). The challenge is how to make it happen. How do we reach these common goals?

The present socially constructed beliefs and assumptions about the good life consist of anthropocentrism, individualism, unlimited growth and technological progress (Glasser 2018). Traditional Western logic is based on linear thinking, where systemic views are not common. A common assumption is that the future can be predicted by examining the past and present and identifying the cause-to-effect relationships between them. This is manifested by a reductionist and simplifying discourse, in which there is no attempt to recognize the interconnection of different parts (Ackoff \& Rovin, 2003). A need for simplification is easy to understand because current life is more complex than before, and people want to have the feeling of good life management in their everyday lives.

It is necessary to question the present socially constructed beliefs and assumptions about the good life because it reproduces society and culture with the harmful metanarrative (Fadel et al. 2015, 98-99). From the systems thinking point of view, there are three basic dimensions of progress, and a hierarchy exists between these dimensions. The sustainability promoting metanarrative is based on the fact that without well-functioning nature, there can be no society because humankind is dependent on thriving ecosystems and the sustainable use of natural resources such as fertile soil, crop pollination, water purification, disease control and climate control. Without a society, there can be no societal functions, including an economy. The solid base of society is built on human rights, social justice and dignity. The good life on the finite planet Earth is not possible without an efficient economy, which is necessary to fulfil the basic needs of people (Giddings et al. 2002; Hediger, 1999; Ott 2003; Salonen \& Konkka, 2015).

Transformative pedagogies can be a tool that leads to societal transformation that underlines 
human solidarity and an expanding moral circle that includes people, animals, plants, and life-supporting ecosystems as well as the abiotic natural resources of the planet Earth. This is not possible to achieve without integrated transdisciplinary heuristics that combine social, natural, behavioural and philosophic points of view (Salonen \& Åhlberg, 2012).

Sustainability requires changes in worldviews, ways of thinking, well-being paradigms and life orientations (Table 1). As a result of self-reflection, it could be found that the best experiences of life are rarely related to consumer goods. Consumption patterns are often driven by wants, not needs. Participation and belonging make us feel good. This kind of social capital can be increased without negative ecological effects. Knowledge, selfexpression, freedom, affection and participation can grow forever without any planetary boundaries (Lehtonen et al. 2018).

Table 1. Principles of change to achieve a sustainable future in the Anthropocene epoch. A path towards full humanness and planetary responsibility by expanding humans' worldview, way of thinking, well-being paradigm, life orientation and moral circle from left to right (adapted from Salonen \& Ålhberg, 2012, 22).

\begin{tabular}{|c|c|c|c|c|c|c|c|c|}
\hline Worldview & \multicolumn{3}{|c|}{ Self-centred Human-centred } & Life-cent & \multirow{2}{*}{\multicolumn{3}{|c|}{$\frac{\text { Ecosystem-centred }}{\text { Systems thinking }}$}} & \\
\hline $\begin{array}{l}\text { Way of } \\
\text { thinking }\end{array}$ & \multicolumn{4}{|c|}{ Atomistic thinking } & & & & \\
\hline $\begin{array}{l}\text { Well-being } \\
\text { paradigm }\end{array}$ & \multicolumn{4}{|c|}{ Accumulation of material goods } & \multicolumn{4}{|c|}{ Harmony, coherence, consciousness } \\
\hline $\begin{array}{l}\text { Life } \\
\text { orientation }\end{array}$ & \multicolumn{2}{|l|}{ Individual } & Collec & & \multicolumn{2}{|c|}{ Planetary } & & \\
\hline Moral circle & $\begin{array}{l}\text { My } \\
\text { family }\end{array}$ & $\begin{array}{l}\text { Friends } \\
\text { and } \\
\text { relatives }\end{array}$ & $\begin{array}{l}\text { My } \\
\text { nation }\end{array}$ & $\begin{array}{l}\text { All } \\
\text { people }\end{array}$ & $\begin{array}{l}\text { Human } \\
\text { beings } \\
\text { and } \\
\text { animals }\end{array}$ & $\begin{array}{l}\text { Human } \\
\text { beings, } \\
\text { animals } \\
\text { and } \\
\text { plants }\end{array}$ & Ecosystems & $\begin{array}{l}\text { Planet } \\
\text { Earth }\end{array}$ \\
\hline
\end{tabular}

An example from the late 15th century helps us to identify what kind of social change is needed in practice. The principles of sustainable development were a reality among sheep herders in Iceland then. They noticed that overcrowding led to soil depletion and erosion. The Icelandic sheep herders had recognized the value of fertile soil as an indispensable prerequisite for their business. For this reason, they decided to unite and estimate the limit to growth in their business and found that the speed of recovery of the pastureland determined the limit of their activity. In practical terms, this was the number of sheep on the slope of a mountain and the fair sharing of sheep between the herders. Subsequently, the sheep herder community safeguarded the vitality of nature in order to ensure the material wealth of the community. The sheep herders adopted a more holistic way of thinking. They gradually changed their life orientation from individual to collective. They also decided to include in their moral circle the whole community and the whole ecosystems on the island, more than only herders' families. This was a concrete path towards full humanness and planetary responsibility in the late $15^{\text {th }}$ century in Iceland.

Implementation of Agenda 2030 requires determined efforts at global, national and local levels. It also involves a range of open questions and information needs (Odlekop et al. 2016). The Government of Finland aims to achieve the sustainable development goals of Agenda 2030 by the Society's Commitment to Sustainable Development (SCSD). The action plan is closely linked to another Government cornerstone project, the formulation of Finland's development policy. SCSD is an instrument produced by the Prime Minister's Office for implementing the Agenda 2030. According to the vision of SCSD "in 2050, every person in Finland will be a valuable member of society. Finland will be an affluent society that lays the foundation for sustainability and provides its citizens, communities and companies with the 
conditions they need to operate sustainably. The carrying capacity of nature is not exceeded and natural resources are used in a sustainable manner. Finland will promote peace, equality and justice, and offer practical and sustainable solutions to the world's problems." To make the vision a reality, Finland has focused on achieving the following eights objectives (Lyytimäki et al. 2016; Commission on Sustainable Development 2016):

1. Equal prospects for health, education and employment,

2. Equal opportunities for all citizens to influence their own lives and common issues,

3. Improving the productivity, profitability and quality of work,

4. Supporting an active civil society,

5. A carbon-neutral society by the year 2050

6. A resource-wise economy and socially responsible business operations,

7. Lifestyles based on non-material consumption and services, and

8. Decision-making that respects nature.

SCSD serves as a long-term framework and instrument of policy coherence for the strategy and programme work of different administrative sectors. Every single Finn can make a public commitment on a digital platform. Moreover, hundreds of measurable and public commitments are already made by companies, municipalities, educational institutions and non-governmental organisations (Lepuschitz, 2014). These commitments transform the whole society towards a more sustainable future (https://sitoumus2050.fi/). However, transformative pedagogies are needed in mainstreaming of sustainable development and this requires adjustment of the values and attitudes of citizens (Commission on Sustainable Development 2016).

\section{Towards transformative pedagogies for sustainable development}

Pedagogical strategy for human development refers to human growth and education in theory and practice (Hämäläinen, 2012, 4). Paul Natorp claimed that all pedagogy should be social (Natorp, 1920). This kind of society oriented pedagogy can be identified as social pedagogy, which is based on the large-scale and holistic theory of human development. A human being is considered as a member of society and of different kinds of communities - a group of people with responsibilities for each other (Hämäläinen, 2003, 73).

Social pedagogy emphasizes holism. It asks what the full potential of the human being is in the context of society, and how the relationship between individuals and society should be organized. It focuses specifically on the social preconditions for individual development and to opportunities to promote people's growth into active citizenship and social responsibility while still fulfilling personal interests and opportunities (Hämäläinen, 2015, 1028). Thus, social pedagogy is about a general rather than special theory of education. It addresses opportunities to contribute to social life, welfare and human development (Hämäläinen, 2012, 12-13; Hämäläinen, 1989, 128; Hämäläinen, 2003, 71).

Social pedagogy is an example of a pedagogy that focuses on changing society (Hämäläinen, 2012 , 9). It deals with fundamental questions of societal order, human development and citizenship education, and it promotes understanding ourselves as human beings (the human domain) and moral actors (the ethical domain). In the Anthropocene epoch, however, it is also important to understand human beings as a part of nature. Transformative pedagogies for a sustainable development transform understanding and conceptions about the interdependence of humans and nature (Laininen, 2018). These three overlapping domains 
together - human, ethics and nature - can promote human flourishing and a sustainable future when they are addressed simultaneously (Ehrenfeld 2008, 58-59). Therefore, truly transformative pedagogies not only focus on human self-awareness but also on deep socialecological transformations in which people define themselves as a part of the surrounding social-ecological reality in harmony (Åhlberg et al. 2014; Salonen \& Bardy 2015; Salonen \& Konkka, 2015).

Martha Rogers (1994) proposes five dimensions for transformative pedagogies:

a) The cognitive dimension relates to knowledge and rational thinking.

b) The affective dimension relates to a combination of emotions and knowledge.

c) The existential dimension means that learners question their own values and ways of life and begin to rebuild perceptions of themselves.

d) Empowerment refers to responsibility, engaging and re-directing life.

e) Action includes making new choices on a personal, communal and political level.

Transformative pedagogies lead to a holistic worldview (Laininen, 2018) because they are based on the epistemic approach to learning (Bateson, 1972; Sterling, 2010). A holistic worldview together with systems thinking and ethics can be a key driver of sustainability in society. The ethical domain of transformative pedagogies is about extending the moral circle to include the entire social-ecological reality. The eco-social approach to education crystallizes into the adoption of a systemic worldview - the extension of the moral circle to cover all human beings, animals, plants and abiotic parts of nature as presented in Table 1. I could start to ask, for example, what chain of people, raw materials and power plants I have connected myself to by turning on the lights in a room. Each everyday choice maintains the system to which it connects citizens. (Åhlberg et al., 2014.)

Human freedoms and responsibilities are, subsequently, based on the dependence on nature and on other people. To achieve this, the moral circle should primarily cover ecological issues on which human beings are dependent and, secondly, social issues to secure the prerequisites for human rights and dignity. Under these conditions is it possible to create a sustainable economy that fulfils the basic needs of all people on Earth. When living on a finite planet, it can be asked whether the best measure for our generation's progress is to ensure as much freedom for future generations as we currently enjoy (Sen, 2009, 250-252). In order to achieve this, it is important to understand that without an ecological foundation no human community can exist, and without the human community there can be no economy. Therefore, all the challenges related to humanity boil down to ecological and social origins, as the economy is an ecosocial process (Lehtonen, et al. 2018; Åhlberg et al. 2014; Salonen \& Konkka, 2015).

Every interpretation of the surrounding reality is a result of social construction (Berger \& Luckmann 1966; Searle 2010; Hacking 1999). However, even the best social construction is unfinished. Therefore, we human beings need each other to question our interpretations, paradigms and way of thinking. Interaction and imagination help people to perceive the weaknesses of their worldview. Correction of them requires humility. Changing the unfinished worldview and the current unsustainable metanarrative requires epistemic learning, that could transform our way of thinking so that we are able to see the world around us differently (Table 1).

Table 2. Developing of transformative pedagogy. Learning approaches, pedagogies and goals to achieve a sustainable future (Bateson, 1972; Sterling, 2010). 


\begin{tabular}{l|l|l} 
& Way of learning & Goal of learning \\
\hline Cognition & Conformative pedagogy & Doing things better \\
\hline Meta-cognition & Reformative pedagogy & Doing better things \\
\hline Epistemic learning & Transformative pedagogy & Seeing things differently \\
\hline
\end{tabular}

Transformative pedagogies include possibilities for a dramatic change in thinking and behaviour. Epistemic learning does not demand learners to do things better or even doing better things. It asks people to see the world around them differently. It can permanently reform learners' consciousness and change their way of being in the world. A possible shift "involves our understanding of relations of power in interlocking structures of class, race, and gender; our body-awarenesses, our visions of alternative approaches to living; and our sense of possibilities for social justice and peace and personal joy." (O'Sullivan et al. 2002, xvii.)

These fundamental changes start with individuals and their change of attitudes, behaviour, and lifestyle. The reflection on transformative action points to the importance of community. In a physically, virtually, socially, politically or culturally defined community, learners find causes that concern them both individually and collectively. It evokes the lifelong learning perspective recognizing non-formal and informal learning throughout the life of an individual. Therefore, transformative actions for sustainability can also be seen as an example of active citizenship (UNESCO 2018, 4-5).

A sustainable future is possible. In the Anthropocene epoch, humankind needs transformative pedagogies with full humanness as a goal. Then human beings can start becoming a part of a bigger story - metanarrative - that is a universal and equal story of a future consisting of peace and dignity (Siirilä et al. 2018). In order to reach this noble goal, transformative pedagogies for sustainable development should be embedded in all subjects in all curricula (Stough et al. 2017).

\section{References}

Ackoff, R. \& Rovin, S. (2003). Redesigning society. Stanford: Stanford University Press Baker, S. (2006). Sustainable Development. London: Routledge.

Bateson, G. (1972). Steps to an Ecology of Mind. San Francisco: Chandler.

Berger, P. \& Luckmann, T. (1966). The social construction of reality. A treatise in the sociology of knowledge. London: Penquin Books.

Bertalanffy, L. (1968). General system theory, foundations, development, applications. New York: George Braziller.

Budowski, G. (1984). Sustainable Use of Species and Ecosystems. In: F.R. Thibodeau \& H.H. Field (Eds.), Sustaining Tomorrow-A Strategy for World Conservation and Development. Hanover: University Press of New England, 56-69.

Commission on Sustainable Development (2016). The Finland we want by 2050 - Society's Commitment to Sustainable Development.

Crutzen, P.J. (2002). Geology of Mankind: The Anthropocene. Nature, 415, 23

Dewey, J. (1916). Democracy and Education: An Introduction to the Philosophy of Education. The Floating Press.

Ehrenfeld, J. (2008). Sustainability by design. A subversive strategy for transforming our consumer culture. New Haven: Yale University

Ehrlich, P.; Kareiva, P.; Gretchen, D. (2012). Securing natural capital and expanding equity 
to rescale civilization. Nature 486, 68-73.

Fadel, C., Bialik, M. \& Trilling, B. (2015). Four-Dimensional Education. The Competencies Learners Need to Succeed. Boston: Center for Curriculum Redesign.

Folke, C., Hahn, T., Olsson, P. \& Norberg, J. (2005). Adaptive governance of socialecological systems. Annual Review of Environment and Resources 30, 441-473

Giddings, B., Hopwood, B. \& O'Brien, G. (2002). Environment, economy and society: fitting them together into sustainable development. Sustainable Development, 10(4), 187-196.

Hediger, W. (1999) Reconciling "weak" and "strong" sustainability. International Journal of Social Economics, 26(7/8/9), 1120-1144.

Hämäläinen, J. (1989). Social pedagogy as a meta-theory of social work education. International Social Work 32, 117-128

Hämäläinen, J. (2003). The Concept of Social Pedagogy in the Field of Social Work. Journal of Social Work 3(1), 69-80.

Hämäläinen, J. (2012). Social Pedagogical Eyes of the Midst of Diverse Understandings, Conceptualisations and Activities. International Journal of Social Pedagogy. 1(1), 3-16.

Hämäläinen, J. (2015). Defining Social Pedagogy: Historical, Theoretical and Practical Considerations. British Journal of Social Work 45(3), 1022-1038

Laininen, E. (2018). Transforming Our Worldview Towards a Sustainable Future. In: Justin W. Cook (Ed.) Sustainability, Human Well-Being and the Future of Education.

Basingstoke: Palgrave Macmillan.

Lepuschitz, K. (2014). Sustainability transition in Finland: Society's commitment to sustainable development. ESDN Case Study $N^{\circ} 18$. Vienna: ESDN Office at the Institute for Managing Sustainability

Lehtonen, A., Salonen, A., Cantell, H., \& Riuttanen, L. (2018). A pedagogy of

interconnectedness for encountering climate change as a wicked sustainability problem. Journal of Cleaner Production 199, 860-867

Lyytimäki, J., Lähteenoja, S., Sokero, M., Korhonen, S., \& Furman, E. (2016). Agenda 2030 in Finland: Key questions and indicators of sustainable development. Helsinki: Prime Minister's Office. Publications of the Government's analysis, assessment and research activities 32/2016

Marsh, G. P. (1965). In D. Lowenthal (Ed.) Man and Nature - Or, Physical Geography as Modified by Human Action. Cambrige, Massachusetts: Belknap Press.

Natorp, P. (1920). Sozial-Idealismus. Berlin: Springer.

Odlekop, J.A., Fontana, L.B., Grugel, J., Roughton, N., Adu-Ampong, E.A., Bird, G.K., Dorgan, A., Vera Espinoza, M.A., Wallin, S., Hammett, D., Agbarakwe, E., Agrawal, A., Asylbekova, N., Azkoul, C., Bardsley, C., Bebbington, A.J., Carvalho, S., Chopra, D., Christopoulos, S., Crewe, E., Dop, M.C., Fischer, J., Gerretsen, D., Glennie, J., Gois, W., Gondwe, M., Harrison, L.A., Hujo, K., Keen, M., Laserna, R., Miggiano, L., Mistry, S., Morgan, R.J., Raftree, L.L., Rhind, D., Rodrigues, T., Roschnik, S., Senkubuge, F., Thornton, I., Trace, S., Ore, T., Valdés, R.M., Vira, B., Yeates, N., Sutherland, W.J. (2016). 100 key research questions for the post-2015 development agenda. Development Policy Review 34(1), 55-82.

O’Sullivan, E., Morrell, M., \& O'Connor, A. (2002). Expanding the Boundaries of Transformative Learning: Essays on Theory and Practice. New York: Palgrave.

Ott, K. (2003). The Case for Strong Sustainability. In: Ott, K. \& P. Thapa (eds.) Greifswald's Environmental Ethics. Steinbecker Verlag.

Pinker, S. (2018). Enlightenment Now. The Case for Reason, Science, Humanism, and Progress. New York: Penguin.

Ripple, W., Thomas, C., Newsome, T., Galetti, M., Alamgir, M., Crist, E., Mahmoud, M., \& Laurance, W. (2018). BioScience 67(12), 1026-1028 
Rockström, J.; Steffen, W.; Noone, K.; Persson, Å.; Chapin, F.S. III; Lambin, E.; Lenton, T.M.; Scheffer, M.; Folke, C.; Schellnhuber, H.J.; Nykvist, B.; De Wit, C.A.; Hughes, T.; van der Leeuw, S.; Rodhe, H.; Sörlin, S.; Snyder, P.K.; Costanza, R.; Svedin, U.; Falkenmark, M.; Karlberg, L.; Corell, R.W.; Fabry, V.J.; Hansen, J.; Walker, B.H.; Liverman, D.; Richardson, K.; Crutzen, C.; Foley, J. (2009). A safe operating space for humanity. Nature 461, 472-475

Rogers, M. (1994) Learning about Global Futures: an exploration of learning processes and changes in adults, DEd Thesis. Toronto: University of Toronto.

Salonen, A. \& Bardy, M. (2015). Ekososiaalinen sivistys herättää luottamusta tulevaisuuteen. Aikuiskasvatus 35(1), 4-15.

Salonen, A. \& Konkka, J. (2015). An Ecosocial Approach to Well-Being: A Solution to the Wicked Problems in the Era of Anthropocene. Foro de Educación 13(19), 19-34.

Salonen, A. \& Åhlberg, M. (2012). The Path towards Planetary Responsibility - Expanding the Domain of Human Responsibility Is a Fundamental Goal for Life-Long Learning in a High-Consumption Society. Journal of Sustainable Development, 5(8), 13-26.

Searle, J. (2010). Making the social world. The structure of human civilization. Oxford: Oxford University Press.

Sen, A. (2009). The idea of justice. Cambridge: Harvard University Press

Siirilä, J, Salonen, A., Laininen, E., Pantsar, T. \& Tikkanen, J. (2018). Transformatiivinen oppiminen antroposeenin ajassa. Ammattikasvatuksen aikakauskirja 20(5)

Sterling S. (2011). Transformative Learning and Sustainability: sketching the conceptual ground, Learning and Teaching in Higher Education 5, 17-33

Sterling, S. (2003). Whole systems thinking as a basis for paradigm change in education: explorations in the context of sustainability. University of Bath.

Stough, T., Ceulemans, K., Lambrechts, W., \& Cappuyns, V. (2017). Assessing sustainability in higher education curricula: A critical reflection on validity issues. Journal of Cleaner Production 172, 4456-4466

UNESCO. (2018). A UNESCO position paper on the future of Education for Sustainable Development (ESD). Revised draft after Technical Consultation Meeting on the Future of ESD, 9-10 July 2018, Bangkok, Thailand.

United Nations. (2015). Transforming Our World: The 2030 Agenda for Sustainable Development. A/RES/70/1.

United Nations. (2016). Sustainable development goals. United Nations. Available at http://www.un.org/sustainabledevelopment/sustainable-development-goals/

Ward, B., \& Dubos, R. (1972). Only One Earth: The Care and Maintenance of a Small Planet. Harmondsworth: Penguin.

WCED (World Commission on Environment and Development) (1987). Our Common Future. Oxford: Oxford University Press.

Wiedmann, T.O.; Schandl, H.; Lenzen, M.; Moran, D.; Suh, S.; West, J.; Kanemoto, K. (2015). The Material Footprint of Nations. Proc. Natl. Acad. Sci. 112, 6271-6276.

Åhlberg, M., Aineslahti, M., Alppi, A., Houtsonen, L., Nuutinen, A-M. \& Salonen, AO (2014). Education for Sustainable Development in Finland. In: Rolf Jucker and Reiner Mathar (Eds.) Schooling for Sustainable Development: Concepts, Policies and Educational Experiences at the End of the UN Decade of Education for Sustainable Development. Berlin-Heidelberg: Springer, 231-233. 